\title{
An Organizational Performance Study Of AACSB International Member Business Schools
}

Robert L. Webster, Ouachita Baptist University, USA

Kevin L. Hammond, University of Tennessee at Martin, USA

\begin{abstract}
Organizations are thought to adopt or evolve to an organizational strategy that will improve organizational effectiveness. Familiar strategies in the business world include a production strategy, low cost strategy, and market orientation strategy. In the world of higher education however organizational strategies may take a different form such as a research strategy, student centered strategy, or a national/international focus. This manuscript reports the results of a national survey examining the levels of reported customer and market orientation toward students and explores their impact on organizational performance. The organizations researched are AACSB-International member business schools. The respondents to the survey are academic vice-presidents of colleges and universities holding membership in AACSB, the premier business school accreditation organization. The academic vice-presidents were chosen as they are thought to hold the management position that can primarily affect the organizational strategy of the academic organizations under their purview. This includes, but is not limited to AACSB member business schools. We use a reworded Narver and Slater (1990) "market orientation" scale and the Jaworski and Kohli's (1993) "overall performance" scale for use in the current research. 116 vice-presidents whose schools are members of AACSB responded to the survey. The manuscript details the data collection and analysis processes, the statistical findings, along with implications and a call for additional subject matter research.
\end{abstract}

Keywords: Market Orientation; Customer Orientation; Organizational Performance; AACSB-International

\section{INTRODUCTION}

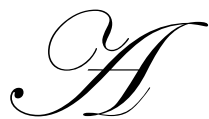

11 forms of organizations, businesses, hospitals, governments and educational providers, seek to attain and maintain high levels of performance. But, can a particular organizational strategy or culture lead to improved organizational performance? And, if so, can such a strategy or culture be described and then be measured quantitatively? And, if measurements can be made will comparisons in measurements between organizations and/or between organizational levels be advantageous in helping organizations improve their performance? This research investigates these questions and attempts to provide insight into how performance of AACSB-International member schools may be influenced by customer (defined in this study as students of the school) and market orientation.

AACSB-International standards for business school accreditation outline requirements that if met lead to accreditation thereby elevating the status of the school as well as indicating superior performance. Additionally, the Baldrige National Quality Program (BNQP 2005) has established the Baldrige Education Criteria for Performance Excellence for universities and other educational organizations, and includes a "student, stakeholder, and market focus category" (BNQP 2005) among the criteria leading to performance excellence. This particular category of criteria suggests that organizations identify potential market segments and determine which ones to pursue, then take steps to learn "key requirements and changing expectations," build relationships, increase loyalty, and determine satisfaction/dissatisfaction of those student/stakeholder markets. The focus category also emphasizes the importance 
of strategic decisions regarding the extent that university business schools may choose to focus on particular markets, and the balance of focus between chosen markets. These decisions may obviously contribute to the culture of the school, encouraging or discouraging attentiveness to students and potential students, parents of students, future employers of graduates, and other student/stakeholder markets.

Market selection and other applications of marketing theory by practitioners within higher education are appropriate and should certainly be beneficial. The idea that organizations of higher education should employ marketing strategies to improve their performance appeared in the literature as early as the 1960s. Kotler and Levy (1969) were pioneers in successfully arguing for broadening the scope of marketing (and the marketing concept) to include higher education as well as other nonbusiness organizations.

In the marketing literature, two terms, the marketing concept and market orientation are defined and described. To help provide clarity and to explain differences and relationships in these terms, the two are briefly discussed below.

- $\quad$ The marketing concept is a philosophy that advocates that a successful organization begins with identifying customer needs and wants, decides which needs to meet, and involves all employees in the process of satisfying customers.

- $\quad$ Market orientation refers to an organizational culture in which everyone in the organization is committed to the customer and adapts in a timely manner to meeting the changing needs of the customer. Market orientation blends a company culture dedicated to providing superior value with successfully achieving a customer focus, acquiring competitor intelligence, and maintaining interfunctional coordination. It is viewed as the implementation of the marketing concept.

This paper reports the results of an empirical study within AACSB member schools examining the levels of self-reported customer and market orientation toward students. Market orientation and customer orientation scores are used as the independent variables in this study. The research then investigates the impact of the independent variables on reported organizational performance, the dependent variable in the study.

\section{DISCUSSION AND LITERATURE REVIEW}

Excellence of performance in higher education is self-evidently important. In accounting and in the other business disciplines, excellence is assessed and assured by the qualification standards of the bodies awarding formal accreditation to business schools (Karathanos and Karathanos 1996). For American business schools, the main accreditation body is AACSB-International (the Association to Advance Collegiate Schools of Business). Performance is ranked more informally in the U.S.A. by the annual guide published by U.S. News and World Report and by the Peterson's web-based educational information resource, both directed at prospective students, their parents and their advisers.

The BNQP (2005), mentioned above, incorporates behaviors and actions indicative of high levels of market orientation as described in the marketing literature (Kohli and Jaworski 1990; Narver and Slater 1990; Jaworski and Kohli 1993; Slater and Narver 1994; Webster, Hammond, and Harmon 2005; Hammond, Webster, and Harmon 2006) throughout the education criteria for performance excellence. Further, the marketing literature (Barksdale and Darden 1971; Houston 1986; Kohli and Jaworski 1990; Narver and Slater 1990; Jaworski and Kohli 1993; Siguaw, Brown, and Widing 1994) supports assertions by practitioner-oriented publications such as the BNQP 2005 that these behaviors and actions result in a greater ability of the organization to achieve its objectives and attain higher levels of performance. The term "market orientation" refers to the extent that an organization uses the marketing concept; Kohli and Jaworski describe the processes required to engender a market orientation as a "distinct form of sustainable competitive advantage" (1990). They state that market orientation consists of "the organizationwide generation, dissemination, and responsiveness to market intelligence" (1990). Narver and Slater agreed with Kohli and Jaworski, proposing three behavioral components (customer orientation, competitor orientation, interfunctional coordination) that "comprehend the activities of marketing information acquisition and dissemination and the coordinated creation of customer value" (1990). 
This study is an extension of previous research (Hammond, Webster, and Harmon 2006), which provided a comparison of the market orientation components to criteria for performance excellence described in the BNQP 2005. Specifically, the criteria require that an educational organization maintain an awareness of and act on the current and future needs of its customers and other stakeholders. They also require the organization to know its strengths, weaknesses, and performance levels relative to competitors, and to support a coordination of effort throughout the organization (toward creating, delivering, and "balancing" customer-stakeholder value and toward achieving high levels of customer-stakeholder satisfaction). The criteria further require an organizational wide effort to gather, disseminate, and act on information regarding the requirements, expectations, and preferences of students and other stakeholders. The BNQP 2005 suggests that students are the key customers of higher education, and suggests that parents and employers of graduates can also be considered "customers" or "stakeholders." We therefore investigate these organizational behaviors described in the market orientation literature as well as the BNQP 2005 as applied toward AACSB member business schools as reported by their academic vice-presidents.

\section{RESEARCH QUESTIONS}

The objectives of this study are to answer the following research questions:

1. Can existing scales be reworded and used to produce reliable and valid measurements of market orientation and overall performance in the context of the university setting?

2. What are the mean levels of customer and market orientation toward students as reported by academic vicepresidents of colleges and universities whose business schools are members of AACSB?

3. How do the mean levels of customer and market orientation of the vice-presidents toward students compare to the levels of customer and market orientation toward customers reported by specialty business managers as catalogued in previous research conducted on businesses in the private sector?

4. What are the mean scores of the organizational performance scale reported by the academic vicepresidents?

5. Do levels of reported customer and market orientation toward students impact the level of reported organizational performance?

To address Research Question 1, we reworded Narver and Slater's (1990) market orientation scale. Narver and Slater explain that this scale, consisting of three behavioral components, is also consistent with the findings of Kohli and Jaworski (1990). The behavioral components of the scale include the activities described by Kohli and Jaworski (1990). The two sets of authors agreed that market orientation is continuous rather than dichotomous and, addressing concerns raised by Barksdale and Darden (1971), is properly measured in terms of behaviors and activities instead of "philosophical notions." Accordingly, the Narver and Slater measure consists of several questions addressing specific behaviors and activities that, together, measure the extent that the organization (or organizational unit) applies the marketing concept. The market orientation scale of Narver and Slater is reworded as necessary and applied to the students. The survey is discussed more fully in the Methodology section of the paper.

"Overall performance" is measured using the Jaworski and Kohli (1993) two-item measure that is based on executive opinion of performance. This subjective measure incorporates differences in performance goals that exist from school to school by simply requesting the vice-presidents indicate the recent overall performance of their business schools, from poor to excellent. The wide range of possible performance goals, then, is not assumed in the survey for any of the schools but is left for the respondent to decide which goals should influence their responses. Each respondent should answer the questions about actual overall performance relative to the expectations and performance goals of the business school. Slater and Narver (1994) echo Jaworski and Kohli's defense of the use of subjective performance measures, noting that the measures "are used commonly in research on private companies or business units of large corporations." Slater and Narver (1994) also noted the "strong correlation between subjective assessments and their objective counterparts" found in previous business research.

Research question 1 is addressed through psychometric analysis of the scales. The scales and their development are more fully discussed in the Methodology section of this paper and the psychometric analysis is addressed in the Results section. 
To answer research question 2, the reported customer and market orientation mean scores of the vicepresidents are calculated for the four dimensions of market orientation (customer orientation, competitor orientation, internal coordination, and overall market orientation - the numerical average of the other three).

To answer research question 3, the mean scores of the vice-presidents are compared to the mean scores of specialty business managers as reported by Narver and Slater (1990). The general hypotheses were that there were no difference between the customer and market orientation scores of the business mangers and the vice-presidents. These hypotheses were tested by way of a series of t-tests that compared mean scores of the vice-presidents to those of the business managers. For each comparison, t-tests were conducted separately on the four components of market orientation.

To answer question 4, the mean scores of the organizational performance scale are computed from the inputs from the academic vice-presidents.

To address question 5, regression models are constructed and analysis of variance of the regression models is undertaken to determine if the independent variables, those being the three constructs of market orientation (customer orientation, competitor orientation, and interfunctional coordination), have a significant statistical effect on the dependent variable, organizational performance.

\section{METHODOLOGY}

Data for the study were collected by way of a mailed survey. Survey instruments along with a cover letter were mailed to academic vice-presidents of schools of business located in the United States holding membership in AACSB-International. As key informants (Campbell 1995; Phillips 1981), the vice-presidents were asked to complete the surveys and return them in business reply envelopes that were provided. Of the total survey instruments mailed, 116 were completed and returned. The response rate was $21 \%$. Data for market orientation and for overall performance of the business schools were gathered from the respondents through the use of scales mentioned above. Anticipating that some respondents may have difficulty with the concept of students as a market (or customers) of higher education, we do not use those terms in the survey. We simply refer to students as students. We also avoided the terms marketing, marketing concept, and market orientation in the survey and the cover letter. Churchill (1979) suggests that the appropriateness of scales borrowed from other studies needs to be addressed before survey research is accomplished. Therefore, all our scale items were pre-tested before mailed. We first consulted with several vice-presidents, deans, chairs, and other university administrators. These consultations resulted in a cover letter that more clearly defined the purpose of the research and rewording of several questionnaire items.

To measure market orientation, we chose Narver and Slater's (1990) construct (MKTOR), which consists of several questions addressing specific behaviors and activities which, together, measure the extent that the organization (the business school in this case) applies the marketing concept. The scale addresses concerns raised by Barksdale and Darden (1971) that market orientation is properly measured in terms of behaviors and activities instead of "philosophical notions." A seven point response scale is used ranging from one (1) "not at all" to seven (7) "to an extreme extent." Scores above the midpoint (4.0) indicate application by the respondent of the marketing concept; scores below the midpoint indicate a lack of application by the respondent. Questions from the original scale were modified somewhat to conform to the vocabulary prevalent in academic institutions and, as noted above, to avoid referring to students as "markets" or "customers." We combine the questions to form three subscales that measure the market orientation components (customer orientation, competitor orientation, and interfunctional coordination), matching Narver and Slater's methodology. The subscales combine to form an overall measure of market orientation, also matching Narver and Slater's methodology. 15 questions were used in the collection of the customer and market orientation data. The questions and explanatory information about the survey questions may be found in appendix 1 at the end of the paper.

"Overall performance" is measured using the subjective Jaworski and Kohli (1993) two-item measure that is based on executive opinion of performance. No specific performance goals are assumed for the respondents. Each respondent is requested to answer the two questions about actual recent overall performance relative to the 
expectations and performance goals of their organization, in this case the business school. Possible responses on the seven point scale range from poor (1) to excellent (7). The questions and explanatory information about the survey questions may be found in appendix 2 at the end of the paper. Slater and Narver (1994) defend the use of subjective performance measures, noting that the measures "are used commonly in research on private companies or business units of large corporations" as well as the "strong correlation between subjective assessments and their objective counterparts" indicated in previous research.

The possibility of nonresponse bias was investigated by comparing early and late respondents (Armstrong and Overton 1977). The tests indicated no significant differences between early and late respondents (at the .10 level of significance). Also, Berdie (1989) found that, even in the event of nonresponse bias in mail surveys, typically the bias did not alter the survey findings. We proceeded on the basis that significant nonresponse bias did not exist.

Narver and Slater (1990) reported market orientation scores for three separate types of businesses: commodity, specialty, and distribution. We believe schools of business demonstrate more of the characteristics of specialty businesses than the characteristics of the commodity or distribution businesses. The commodity and distribution businesses in the Narver and Slater study produced and sold generic products designed for a wide range of customers. The specialty business firms produced and sold products that were individualized (relative to the commodity products) for specific customer orders. By adapting its generic or base product, the specialty products firm creates superior value and thereby provides more benefit to the customer. This type of firm is challenged to constantly monitor the competitive environment and to be vigilant for changes in the customer requirements. Likewise AACSB-International schools of business seek to provide a product that is individualized through its programs of study or majors. AACSB-International schools would argue that a superior product (relative to nonmember schools) is provided that would benefit its customers (or students). We therefore used the market orientation scores for specialty business as reported by Narver and Slater (1990) for our comparisons.

\section{RESULTS}

The reworded Narver and Slater scale was subjected to reliability analysis, exploratory factor analysis and confirmatory factor analysis (Wheaton, Muthen, Alwin, \& Summers 1997; Bentler \& Bonett 1980; Marsh \& Hocevar 1985; Bentler 1990; Browne \& Mels 1992; and Browne \& Cudeck 1993). Results of these analyses indicated satisfactory reliabilities (ranges from .73 to .91), satisfactory item-to-total correlations (ranges from 0.3 to 0.8 ), exploratory factor loadings ranging from 0.33 to 0.89 , and confirmatory factor loading ranging from 0.36 to 0.82. Additionally, the confirmatory factor analysis demonstrated generally acceptable fit. These test results included comparative fit index measures ranging from .784 to 1.000 , a Tucker-Lewis index ranging from .702 to 1.000, and the CMIN/DF ranging from 2.05 to 2.56. The RMSEA low values at the $90 \%$ confidence interval fell below 0.10 for all scales. The Pearson correlation coefficient for the two-item overall performance scale was computed to be .709 (sign. .000), indicating reliability for this two-item scale. These results indicate that research question 1 may be answered in the affirmative.

Table 1 presents the mean score and standard deviation for the three market orientation constructs and the mean score and standard deviation for the overall market orientation score (the arithmetic average of the three component scores) as well as the mean score and standard deviation for the performance indicator. All scores are compiled from the data received from the vice-presidents. The information in this table provides answers to research questions 2 and 4.

Table 1: Descriptive Statistics

Mean Scores for the Three Market Orientation Constructs, Overall Market Orientation Score, and Performance Indicator Mean Score as Reported by Academic Vice-Presidents of AACSB Member Schools (seven point scales)

\begin{tabular}{lccc}
\hline Description & Mean & Std. Dev. & N \\
MO-Customer & 4.775 & 0.880 & 116 \\
MO-Competition & 4.168 & 1.021 & 116 \\
MO-Coordination & 4.441 & 1.003 & 116 \\
MO-Overall & 4.461 & 0.968 & 116 \\
Performance & 5.295 & 1.017 & 116 \\
\hline
\end{tabular}


Table 2 presents the results of four separate t-tests undertaken to determine if statistically significant differences exist between the mean scores, associated with the components of market orientation, of business managers and the academic vice-presidents. As can be seen in the table, the business managers reported higher levels for each of the three constructs as well as for overall market orientation. The business managers reported higher scores in absolute terms than did the vice-presidents and in three of the four t-tests, the scores were found to be different by a statistically significant margin. The information in Table 2 answers research question 3 .

Table 2

Mean scores and t-test Results for Academic Vice-Presidents versus Specialty Business Managers Market Orientation Measurements ( 7 point scale)

\begin{tabular}{lcl}
\hline Market Orientation Construct: & $\begin{array}{c}\text { Business } \\
\text { Managers } \\
\mathbf{n = 7 5}\end{array}$ & $\begin{array}{c}\text { Vice } \\
\text { Presidents } \\
\mathbf{n = 1 1 6}\end{array}$ \\
\hline & Mean & Mean \\
Customer Orientation & 5.05 & $4.78^{*}$ \\
Competitor Orientation & 4.71 & $4.17^{*}$ \\
Interfunctional Coordination & 4.53 & 4.44 \\
Overall Market Orientation & 4.77 & $4.46^{*}$ \\
\hline
\end{tabular}

*significant at .05 compared to Business Managers

The regression models developed to answer research question 5 were:

$\mathrm{Y}=\mathrm{b}_{0}+\mathrm{b}_{1} \mathrm{x}_{1}+\mathrm{b}_{2} \mathrm{x}_{2}+\mathrm{b}_{3} \mathrm{x}_{3}$ where:

$\mathrm{Y}=$ mean score of the two-item performance scale as reported by the academic vice presidents

$\mathrm{b}_{0}=$ intercept

$\mathrm{x}_{1}=$ mean score of the customer orientation construct as reported by the academic vice presidents

$\mathrm{x}_{2}=$ mean score of the competitor orientation construct as reported by the academic vice presidents

$\mathrm{x}_{3}=$ mean score of the interfunctional coordination construct as reported by the academic vice presidents

and,

$\mathrm{Y}=\mathrm{a}+\mathrm{b}_{1} \mathrm{x}_{1}$ where:

$\mathrm{Y}=$ mean score of the two-item performance scale as reported by the academic vice presidents

$\mathrm{a}=$ intercept

$\mathrm{x}_{1}=$ mean score of the customer orientation construct as reported by the academic vice presidents

The simple regression model was constructed for two specific reasons. First, the coefficient of the customer orientation construct in the multiple regression model was found to be statistically significant. Secondly, the mean score for the customer orientation was the highest of all the components of market orientation.

Tables 3 and 4 that follow present the results of the analysis of variance of the two regression equations and yield that both the regression models are statistically significant in that both show that organizational performance is positively affected by higher market orientation scores in the first instance and singularly by customer orientation scores in the case of the simple regression. These two models and the analysis that follow provide insight and answers to research question 5 . 
Table 3

F-Test Results From The Analysis Of Variance Of The Regression Model Market Orientation Component Scores Effect On Performance For AACSB Academic Vice-Presidents

\begin{tabular}{lcc}
\hline Source & F & Significance \\
\hline Model & 15.572 & .000 \\
Intercept & 25.900 & .000 \\
MO/Customer & 13.953 & .000 \\
MO/Competitors & 1.240 & .268 \\
MO/Coordination & 1.920 & .169 \\
\hline
\end{tabular}

*R Squared=.310 (Adjusted R Squared=.290)

Table 4

F-Test Results From The Analysis Of Variance Of The Regression Model Market Orientation Toward Customer Effect On Performance For AACSB Academic Vice-Presidents

\begin{tabular}{lcc}
\hline Source & F & Significance \\
\hline Model & 45.555 & .000 \\
Intercept & 27.305 & .000 \\
MO/Customer & 45.555 & .000 \\
\hline
\end{tabular}

*R Squared=.297 (Adjusted R Squared=.290)

\section{IMPLICATIONS}

This research finds that customer and market orientation do indeed affect organizational performance, at least as reported by the academic vice-presidents. Higher levels of both the customer orientation construct and the three construct market orientation model are both significant models (variables) in explaining changes in levels of reported performance. The research findings also demonstrate that businesses perceive a greater importance and have made greater progress in the implementation of the marketing concept vis-à-vis university schools of business as perceived by their academic vice-presidents. This research found, as has previous research conducted on business organizations, that organizations may improve their performance by increasing levels of customer and market orientation.

The academic vice-presidents reported lower levels of market orientation in their organizations than did their business counterparts. This may signal that the vice-presidents are either not familiar with the marketing concept, customer and market orientation, or reject the idea that students are customers of the school, or all of the above. However, a significant opportunity would seem to exist to improve business school performance for schools that will put more effort into customer and market orientation. As students of the university may be viewed as the most visible of the numerous markets served, customer and market orientation efforts focused at students would seem to have the potential for the fastest and highest payoff. Examples of such payoffs, all of which might correctly be viewed as performance indicators might include:

1. An increase in enrollment within the business school

2. An increase in the hit rate (increase in percent of applicants that actually enroll)

3. An increase in the number of business majors

4. An increase in the retention rate of current business students

5. An increase in future giving by business school alumni

6. An improvement in rankings by outside organizations

In view of Narver and Slater (1990) and Kohli and Jaworski (1993) findings that enhanced levels of market orientation will improve the competitive advantage of organizations, business schools appear to be organizations ripe to take advantage of the market orientation concept. Focus on creating a market orientation culture should serve both schools and their various stakeholders, not just students, in more effectively achieving business school objectives. Our conclusions are tempered by the findings of Noble, Sinha, \& Kumar (2002) and Haugland, Myrtveit, \& Nygaard (2007) that there appears to be no single strategic orientation that leads to superior 
performance in every case; and as previously stated, building a market orientation culture within an organization is not a quick fix but rather a continuous process.

\section{FUTURE RESEARCH}

The research we report leaves open several related areas of interest for additional study. For example, do customer and market orientation levels vary between different levels of administrative responsibility within the business school or university at large? Other examples include research to determine the impact or influence that variables such as size of a school, school affiliation (AACSB, ACBSP, or neither), admission standards, placement efforts, or recruiting efforts have on customer and market orientation. Also, research on other stakeholders such as parents of students, employers of students, and alumni associated with schools of business would be useful. Such research would further our understanding of the market orientation construct and its application to higher education. Additional research in organizational culture including that of market orientation should be conducted in other nonprofit organizations such as governmental agencies that provide services to the public, and into the non-profit side of the healthcare industry.

\section{AUTHOR INFORMATION}

Robert L. Webster, Ouachita Baptist University. Dr. Webster holds the George Young Endowed Chair of Business at Ouachita Baptist University and serves as the Chairperson of the Accounting Department. $\mathrm{He}$ is a former president of the Southwest Region of the American Accounting Association. He has published extensively in the areas of market orientation, financial analysis, and gender studies. E-mail: websterb@obu.edu. Corresponding author.

Kevin L. Hammond, University of Tennessee at Martin. Dr. Hammond is professor of Marketing at the University of Tennessee at Martin and also serves as the Graduate Program coordinator for the Business graduate programs at the school. He has published widely in the marketing literature with his most recent research dedicated to the subject of market orientation within higher education. E-mail: khammond@utm.edu.

\section{REFERENCES}

1. Armstrong, J. S. \& Overton, T. S. (1977) Estimating nonresponse bias in mail surveys. Journal of Marketing Research, 14 (August), 396-402.

2. Barksdale, H. C. \& Darden, B. (1971) Marketers attitude toward the marketing concept. Journal of Marketing, 35 (October), 29-36.

3. Bentler, P. M. (1990) Comparative fit indexes in structural models. Psychological Bulletin, 107, 238-246.

4. Bentler, P. M. \& Bonett, D. G. (1980) Significance tests and goodness of fit in the analysis of covariance structures. Psychological Bulletin, 88, 588-606.

5. Berdie, D. (1989) Reassessing the value of high response rates to mail surveys. Marketing Research, 1, 5264.

6. BNQP (2005), "Baldrige Education Criteria for Performance Excellence," Baldrige National Quality Program, www.quality.nist.gov/Education_Criteria.htm.

7. Browne, M. W. \& Cudeck, R. (1993) Alternate ways of assessing model fit. In Bollen, K. A. \& Long, K. S. (Eds.) Testing structural equation models. Newbury Park, California: Sage, 136-162.

8. Browne, M. W. \& Mels, G. (1992) RAMONA User's Guide. The Ohio State University, Columbus, Ohio.

9. Churchill, G. A. (1979) a paradigm for developing better measures of marketing constructs. Journal of Marketing Research, 16 (February), 64-73.

10. Dwyer, F. R., \& Welsh, M. A., (1985) Environmental relationships of the internal political economy of marketing channels. Journal of Marketing Research, 22, (November), 397-414.

11. Felton, A. P. (1959) Making the marketing concept work. Harvard Business Review, 37, (July-August), 5565 .

12. Hammond, K L., Webster, R. L., \& Harmon, H. A., (2006) Market orientation, top management emphasis, and performance within university schools of business: implications for universities. Journal of Marketing Theory and Practice, (Winter), Vol. 14, No. 1, 69-85. 
13. Haugland, S.A., Myrtveit, I., \& Nygaard, A. (2007) Market orientation and performance in the service industry: A data envelopment analysis. Journal of Business Research Vol. 60 No. 11, (Nov), 1191-1197.

14. Houston, F. S. (1986) The marketing concept: what it is and what it is not. Journal of Marketing, 50 (April), 81-87.

15. Hunt, S. (1990) Commentary on an empirical investigation of a general theory of marketing ethics. Journal of the Academy of Marketing Science, 18, (Spring), 173-177.

16. Jaworski, B. J. \& Kohli, A. K. (1993) Market orientation: antecedents and consequences. Journal of Marketing, 57 (July), 53-70.

17. Karathanos, D. \& Karathanos, P. (1996) The Baldridge education pilot criteria 1995: An integrated approach to continuous improvement in education. Journal of Education for Business, 71 (May/June), 272276.

18. Kohli, A. K. \& Jaworski, B. J. (1993) Market orientation: the construct, research proposition, and managerial implications. Journal of Marketing, 54 (April), 1-18.

19. Kotler, P. (1980) Marketing Management: Analysis. Planning and Control, (4th ed.) Englewood Cliffs, NJ: Prentice-Hall, Inc.

20. Larson, R. \& Catton, W., Jr. (1959) Can the mail-back bias contribute to a study's validity? American Sociological Review, XXIV, 243-245.

21. Levitt, T. (1969) The Marketing Mode. New York: McGraw-Hill Book Company.

22. Marsh, H. W. \& Hocevar, D. (1985) Applications of confirmatory factor analysis to the study of selfconcept: first -and higher-order factor models and their invariance across groups. Psychological Bulletin, 97, 562-582.

23. McNamara, C. P. (1972) The present status of the marketing concept. Journal of Marketing, 36 (January), 50-57.

24. Morse, R. J. \& Flanigan, S. M. (2000) America's best colleges-how we rank them. U.S. News and World Report, (September 11), 104-105.

25. Narver, J. C., Park, S. Y. \& Slater, S. F. (1992) Market orientation, information, and marketing strategies. American Marketing Association Summer Educators Conference.

26. Narver, J. C. \& Slater, S. F. (1990) The effect of a market orientation on business profitability. Journal of Marketing, 54 (October), 20-35.

27. Noble, C. H., Sinha, R. J., \& Kumar, A. (2002) Market orientation and alternative strategic orientations: a longitudinal assessment of performance implications. Journal of Marketing, 66 (October), 25-39.

28. Peterson's Guide to Four Year Colleges, 2001, 31st ed. (2000) Lawrenceville, NJ: Peterson's/Thomson Learning.

29. Siguaw, J. A., Brown, G. \& Widing, R. E., II, (1994) The influence of the market orientation of the firm on sales force behavior and attitudes. Journal of Marketing Research, 31 (February), 106-116.

30. Slater, S. F. \& Narver, J. C. (1994) Does competitive environment moderate the market orientationperformance relationship? Journal of Marketing, 58 (January), 46-55.

31. Webster, R.L., Hammond, K.L., \& Harmon, H.A. (2005) Comparing market orientation culture of businesses and schools of business: an extension and refinement. Psychological Reports, 96, 377-382.

32. Wheaton, B., Muthen, B., Alwin, D. F., \& Summers, G. F. (1977) Assessing reliability and stability in panel models. In Heise, D. R. (Ed.) Sociological Methodology 1977. San Francisco: Jossey-Bass, 84-136. 


\section{APPENDIX 1}

Market Orientation Survey Questions Sent to Academic Vice-Presidents of AACSB Schools of Business

1. Our objectives are driven by satisfaction of our students.

2. We measure satisfaction of our students systematically and frequently.

3. Those responsible for recruiting students regularly share information within our business school/institution concerning competitor's strategies.

4. Our market strategies (such as recruiting and retention) are driven by our understanding of the possibilities for creating value for our students.

5. We respond rapidly to competitive actions that threaten us.

6. We constantly monitor our level of commitment and orientation to students.

7. University administration regularly discusses competitors' strengths and strategies.

8. All levels of administration understand how the entire institution can contribute to creating value for students.

9. We give close attention to service of students after enrollment.

10. Our strategy for competitive advantage is based on our understanding of our students needs.

11. We encourage other staff and faculty outside of recruiting/administration to meet with our prospective students.

12. All of our departments are responsive to and integrated in serving students.

13. Information on recruiting successes and failures are communicated across functions in the business school/institution.

14. We share information and coordinate resource use with other units in the institution.

15. We target potential students where we have, or can develop a competitive advantage.

Each question answered on a 7 point scale: 1=Not At All, 7=to An Extreme Extent. Questions 1, 2, 4, 6, 9, and 10 relate to the Customer Orientation construct/dimension, Questions 3, 5, 7, 11, and 15 relate to the Competitor Orientation, Questions 8,12,13, and 14 relate to Organizational Coordination. The Overall Marketing Orientation score is computed by averaging the mean scores of the other three sets of questions.

\section{APPENDIX 2}

Performance Measurement Questions Sent to Academic Vice-Presidents of AACSB Schools of Business

1. Overall performance of the school of business last year was.

2. Overall performance of your school of business relative to major competitors last year was.

Both questions answered on a 7 point scale: $1=$ Poor, $7=$ Excellent 